\title{
BIOCHEMICAL PROCESSES IN CHERNOZEM SOIL UNDER DIFFERENT FERTILIZATION SYSTEMS
}

\author{
Ecaterina Emnova \\ Institute of Genetics and Plant Physiology, Moldavian Academy of Sciences \\ E-mail: kateemnova@yahoo.com, phone+3732 774 047,fax +3732 556180
}

\begin{abstract}
The aim of this research was to assess how biochemical processes driven by microbial activity and extracellular enzymes have developed in the long-term under farming system with different fertilizer and crop types. It was concluded that the crop types had a more considerable impact on the soil biochemical processes compared to long-term Org or mixed Min+Org fertilizers amendments.
\end{abstract}

Keywords: soil, fertilization, enzymatic activity, organic N mineralization

\section{Introduction}

The intensification of agriculture in the $20^{\text {th }}$ century has caused several environmental problems [1]. High $\mathrm{N}$ fertilizer rates have increased nitrate leaching and $\mathrm{N}_{2} \mathrm{O}$ emissions from cropping systems [2]. The intensive soil cultivation of arable land has lead to a loss of soil $\mathrm{C}$, thereby contributing to anthropogenic $\mathrm{CO}_{2}$ emission [3]. These issues spurred research interest in less intensive agricultural management practices, and their potential to reverse some of modern agriculture's negative side effects [4]. We are to increase our awareness of how soil management affects soil fertility (e.g. nutrient cycling, soil structure and water holding capacity).

Since mineralization of soil organic substrates and the release of nutrients and elements are due to the heterotrophic activity of microbial decomposer compartment, this subsystem of terrestrial ecosystems gained importance [5]. The impact of management practices on the flow of $\mathrm{C}$ and $\mathrm{N}$ trough ecosystems is largely mediated trough the soil microbial community. The $\mathrm{C}$ derived from fresh or native soil organic matter that is used by microbes is either mineralized to $\mathrm{CO}_{2}$ or it is put to anabolic use in production of biomass (new or maintenance) or egested as cellular metabolites (e.g. enzyme production) [6]. Soil microbes produce extracellular enzymes that mineralize organic matter and release carbon and nutrients in forms that can be assimilated. The current understanding is that mineralization of soil organic matter is governed by several concurrent processes: 1) destabilization via oxidation/hydrolysis, desorption and diffusion and 2) the size, community composition and metabolic activity of the microbial biomass [7-8]. It is thought that substrates must pass through the dissolved phase of organic $\mathrm{C}$ pool to reach and pass through microbial membranes [9].

Microbial biomass carbon $\left(\mathrm{C}_{\text {mic }}\right)$ and related parameters such as microbial quotient $\left(\mathrm{C}_{\text {mic }}: \mathrm{C}_{\text {org }}\right)$, basal soil respiration $\left(\mathrm{C}-\mathrm{CO}_{2}\right.$ rate $)$, and metabolic quotient $\left(\mathrm{qCO}_{2}\right)$ are widely used with the objective of understanding of microbial responses to various soil management practices [5, 10-11]. These parameters were specified by Nannipieri et al. [12] as the general parameters of soil biochemical properties (directly related to microbial activity) and proposed as ecophysiological indicators of biological soil quality [5].

The aim of this research was to evaluate the intensity of certain soil biochemical processes (e.g. soil organic C mineralization) at Organic and mixed Mineral+Organic fertilization of typical chernozem in crop rotation dynamics (for 6 years) by use of eco-physiological indicators of biological soil quality: microbial biomass carbon, basal soil respiration, as well as, microbial and metabolic quotients.

\section{Experimental}

Soil sampling was performed from a long-term field crop experiment, which has been established in 1971 at the Balti steppe and are supported by Research Center "Selectia" (Balti, $140 \mathrm{~km}$ North of Chisinau) [13-14]. The soil is classified as a typical chernozem (black) soil (silt loam) with $\mathrm{C}_{\text {org }}$ reach horizon up to $92 \mathrm{~cm}$. Soil organic matter (SOM) content initially was $4.65 \%$ (correspondingly, $\mathrm{C}_{\text {org }}$ constituted $2.70 \%$ ) in $0-20 \mathrm{~cm}$ layer. The $\mathrm{pH}$ value $-6.6-$ 7.1 (water) and 6.2 (salt solution). Total $\mathrm{N}$ constituted $0.24-0.26 \%$; $\mathrm{P}-0.12-0.13 \% ; \mathrm{K}-1.2-1.4 \%$. Two treatments representing organic (Org) and mixed mineral-organic (Min+Org) fertilization were selected for comparative research of soil biochemical properties, because of both are known to be able to maintain the SOM. But both provide different increases of crop productivity in frames of studied crop rotation [15]. Soil samples were taken June 14-16, 2010 (at active crop growth phase) by an auger from the top layer $(0-20 \mathrm{~cm})$ of arable field plots. Samples were taken from each of 4 replicates per treatment by combining 5 soil cores inside of each replicate, in total 48 samples. After removing vegetal rests and stones soil was passed through $2 \mathrm{~mm}$ sieve. Samples were stored at $4^{\circ} \mathrm{C}$ no longer than one month necessary for set of biochemical analysis. The aliquots of air-dried soil samples were used for chemical parameters determination.

Microbial biomass carbon $\left(C_{\text {mic }}\right)$ assay was conducted by use of rehydratation method [16]. Soil samples (2 replicates till $5 \mathrm{~g}$ for each of treatment) were oven dried at $65-70^{\circ} \mathrm{C}$ for $24 \mathrm{~h}$, resulting in disruption of the microbial cell wall permeability. Repeated rehydratation of dry soil samples with $0.5 \mathrm{M} \mathrm{K}_{2} \mathrm{SO}_{4}$ at a ratio 1:2 (w/v) resulted in 
microbial cell destruction and release of microbial carbon into solution. An additional 2 replicates of $5 \mathrm{~g}$ fresh soil samples were placed in refrigerator to serve as controls which were treated in the same way. $\mathrm{K}_{2} \mathrm{SO}_{4}$-extractable organic $\mathrm{C}$ concentrations in the dried and fresh soil samples were simultaneously measured using dichromate oxidation. The aliquote $1.6 \mathrm{ml}$ of filtered soil extract was carefully mixed in tube with $2.4 \mathrm{ml}$ of dichromate solution: $1.28 \mathrm{~g} \mathrm{~K}_{2} \mathrm{Cr}_{2} \mathrm{O}_{7}$ in $400 \mathrm{ml}$ of deoinized water is dissolved in $2 \mathrm{~L}$ of $\mathrm{H}_{2} \mathrm{SO}_{4}\left(\mathrm{~d}=1.84 \mathrm{~g} / \mathrm{cm}^{3}\right)$. The mixture was incubated at $140^{\circ} \mathrm{C}$ for $20 \mathrm{~min}$. The optical density after cooling is measured at $340 \mathrm{~nm}$ against of blank mixture of reagents without soil salt extract. The amount of carbon in the samples was calculated by the following formulae: $\mathrm{C}_{\mathrm{d}}=\left(\mathrm{OD}_{\mathrm{d}}-\mathrm{OD}_{\mathrm{b}}\right) \cdot \mathrm{V} / \mathrm{k}_{1} \cdot \mathrm{a}$, and $\mathrm{C}_{\mathrm{f}}=\left(\mathrm{OD}_{\mathrm{f}}-\mathrm{OD}_{\mathrm{b}}\right) \cdot \mathrm{V} / \mathrm{k}_{\mathrm{l}} \cdot \mathrm{a}$, where $\mathrm{OD}_{\mathrm{d}}$ and $\mathrm{OD}_{\mathrm{f}}$ are the optical densities of dried and fresh samples, respectively; $\mathrm{OD}_{\mathrm{b}}$ is the optical density of blank probe with salt solution instead of salt extract; $\mathrm{V}$ represents the volume of salt extract, ml; $\mathrm{a}$ - is the the weight of soil sample, $\mathrm{g}$; and $\mathrm{k}_{1}$ is the coefficient for transfer from optical dencity to carbon concenration according to calibration curve with glucose. Biomass $\mathrm{C}$ ( $\mu \mathrm{g} \mathrm{C}$ per g oven dry soil) was calculated from the expression $B_{c}=\left(C_{d}-C_{f}\right) / k_{c}$ where $\left(C_{d}-C_{f}\right)$ is the difference of $C$ measured in dried and fresh sand samples, $\mu g C ; k_{c}$ (the portion of cell components released in solution after drying-rehydratation procedure) was 0.25 [16].

Basal soil respiration (C-CO $\mathrm{C}_{2}$ elimination) was determined by adopted method proposed by Isermeyer [17]. Briefly, soil (25-50 g of dry soil, adjusted to water content $40 \%$ WHC was weighted at the bottom of $1 \mathrm{~L}$ glass jars containing two vessels with $10 \mathrm{ml}$ of distilled water for air humidifying and $20 \mathrm{~mL}$ of $1 \mathrm{M} \mathrm{NaOH} \mathrm{for} \mathrm{CO}_{2}$ trapping. The jars were sealed (air-tight) and incubated at $21^{\circ} \mathrm{C}$ in the dark for 7-14 d. $\mathrm{CO}_{2}$ released during soil incubation was trapped in $\mathrm{NaOH}$ and determined by titrimetric analysis. Before analysis $0.5 \mathrm{M} \mathrm{BaCl}_{2}$ was added to the $\mathrm{NaOH}$ solution to remove carbonates. Residual $\mathrm{NaOH}$ was titrated with $0.1 \mathrm{M} \mathrm{HCl}$ in the presence of phenolphtalein indicator. The soil respiration was recorded as $\mu \mathrm{g} \mathrm{C}-\mathrm{CO}_{2} \mathrm{~g}^{-1}$ dry soil $\mathrm{h}^{-1}$ at $21^{\circ} \mathrm{C}$ as the average rate during the whole 7-14 days incubation.

Metabolic quotient $\left(q \mathrm{CO}_{2}\right)$ or the quantity $\mathrm{C}-\mathrm{CO}_{2}$ produced per unit of microbial biomass $\mathrm{C}$ per unit of time was calculated as a ratio $C-\mathrm{CO}_{2}: \mathrm{C}_{\text {mic }}$ and was expressed in $\mathrm{mg} \mathrm{C}-\mathrm{CO}_{2} \mathrm{~g}^{-1} \mathrm{C}_{\text {mic }} \mathrm{h}^{-1}[18]$.

Total organic carbon $\left(C_{\text {org }}\right.$ ) was assayed using air-dried soil samples by wet oxidation with dichromate in an acid medium and evaluation of the excess of dichromate according to the method of Tiurin [19]. The value of total $\mathrm{C}_{\text {org }}$ is recorded as \% of dry soil mass.

Microbial quotient was calculated as a ratio $C_{m i c}: C_{\text {org }}$ and expressed in \% of total organic C [20].

Statistical analysis. Two-way ANOVA (StatSoft STATISTICA 7.0) was conducted with fertilizer and crop type as fixed factors. Differences between means within a crop types for each investigated parameter were identified using paired t-tests.

\section{Results and Discussion}

Total organic carbon ( $\boldsymbol{C}_{\text {org }}$ ) of typical chernozem soil from Balti steppe under long-term agricultural use with 6-field crop rotation and two fertilization systems was ranged, between 2,36\%-2,59\% and 2,40\%-2,63\%, respectively, for Org and Min+Org fertilization systems (table 1). According to two-way ANOVAs data, both independent factors the fertilization system and the crop types significantly $(\mathrm{P}<0.05)$ influence the principal component of soil fertility (table 2). Mean values of total organic $C$ were significant higher in soil amended by mixed Min+Org fertilizers and revealed the significant differences depending on cultivated crop type. The soil under winter wheat was characterized by the least values of $\mathrm{C}_{\text {org }}$ at both fertilization systems, though it follows after mixture of vetch + oats in crop chain.

Microbial biomass carbon $\left(\boldsymbol{C}_{\text {mic }}\right.$ ) serves the index of soil microbiological and biochemical potential. The size of microbial biomass carbon in typical chernozem soil cultivated with six different crops was influenced significantly ( $\mathrm{P}$ $<0.05$ ) by the crop type and the kind of investigated fertilizers, with the evident tendency of increase at mixed Min+Org fertilizers amendment (tables 1-2). It could be explained by bigger amount and accessibility of mineral nutrients for soil microorganisms at sum action of Min+Org fertilizers. Of six crops cultivated in studied crop rotation the soils under winter wheat and sugar beet characterized with significantly $(\mathrm{P}<0.05)$ lower size of microbial biomass despite of adequate soil fertilization. It seems in contradiction with results of other researchers [21-23], which reported that the identity of the plant species did not influence the soil microbial biomass. However, it was shown that though soil bacterial and fungal biomass did not differ between soils of different plant species the microbial community structures did, due to the quality of rhizosphere carbon [24]. The idea that plant species may have specific effects on the carbon flow into soil microorganisms was confirmed by Ladygina and Hedlund [21] when regarding the active carbon allocation from a plant to the microorganisms. These data allow the assuming that winter wheat's and sugar beet's root exudation (organic rhizodeposition) could allocate less carbon into microbial biomass in comparison to the other four crops in studied crop rotation.

Microbial quotient $\left(\boldsymbol{C}_{\text {mic }}: \boldsymbol{C}_{\text {org }}\right.$ ) gives the insight into the capability of a soil to support the microbial growth [25], that is, it reflects the soil carbon available for growth [20]. Thus, it is expected that soils with better quality will have higher microbial quotient [10,20]. According to results of this study (table 1) the two used fertilization systems (Org vs. Min $+\mathrm{Org}$ ) insignificantly differed by the available $\mathrm{C}$ resource for microbial growth, but crop types did (table 2). Typical chernozem cultivated with winter wheat and followed sugar beet demonstrated the lowest microbial quotient 
(0.7-0.8\%), the sequence of crops spring barley-sunflower-vetch+oats characterized by higher values $(0.9-1.0 \%)$, but the soil under corn for grain placed in the middle of crop chain was the bend point (0.8-0.9\%).

Table 1

Eco-physiological indicators of soil quality reflecting the intensity of soil biochemical processes

\begin{tabular}{|c|c|c|c|c|c|}
\hline Parameter & $\begin{array}{c}\text { Microbial } \\
\text { biomass carbon, } \\
\mathrm{C}_{\text {mic }}\end{array}$ & $\begin{array}{l}\text { Microbial } \\
\text { quotient, } \\
\mathrm{C}_{\text {mic }}: \mathrm{C}_{\text {org }}\end{array}$ & $\begin{array}{c}\text { Basal soil } \\
\text { respiration, } \\
\mathrm{C}-\mathrm{CO}_{2} \text { rate }\end{array}$ & $\begin{array}{l}\text { Metabolic } \\
\text { quotient, } \\
\text { qCO }_{2}\end{array}$ & $\begin{array}{c}\text { Total organic } \\
\text { carbon, } \\
C_{\text {org, }}\end{array}$ \\
\hline $\begin{array}{c}\text { Units of } \\
\text { measurement }\end{array}$ & $\mu \mathrm{g} \mathrm{C} \mathrm{g}{ }^{-1}$ dry soil & $\%$ & $\begin{array}{c}\mu \mathrm{g} \mathrm{C}-\mathrm{CO}_{2} \mathrm{~g}^{-1} \text { soil } \\
\mathrm{h}^{-1} \text { at } 21^{\circ} \mathrm{C}\end{array}$ & $\begin{array}{c}\mathrm{mg} \mathrm{C}-\mathrm{CO}_{2} \mathrm{~g}^{-1} \mathrm{C}_{\text {mic }} \\
\mathrm{h}^{-1}\end{array}$ & $\%$ \\
\hline Crop type & \multicolumn{5}{|c|}{ Organic fertilization system } \\
\hline Winter wheat & $176 \pm 8^{a}$ & $0.75 \pm 0.02$ & $0.56 \pm 0.14$ & $3.2 \pm 0.74$ & $2.36 \pm 0.04$ \\
\hline Sugar beet & $177 \pm 23$ & $0.69 \pm 0.09$ & $0.61 \pm 0.08$ & $3.5 \pm 0.80$ & $2.59 \pm 0.04$ \\
\hline Corn for grain & $217 \pm 24$ & $0.88 \pm 0.10$ & $0.77 \pm 0.08$ & $3.6 \pm 0.25$ & $2.46 \pm 0.03$ \\
\hline Spring barley & $240 \pm 11$ & $1.00 \pm 0.07$ & $0.35 \pm 0.16$ & $1.5 \pm 0.65$ & $2.40 \pm 0.20$ \\
\hline Sunflower & $236 \pm 5$ & $0.96 \pm 0.03$ & $0.60 \pm 0.16$ & $2.5 \pm 0.66$ & $2.45 \pm 0.05$ \\
\hline \multirow[t]{2}{*}{ Vetch+oats } & $228 \pm 31$ & $0.89 \pm 0.10$ & $0.56 \pm 0.17$ & $2.6 \pm 1.00$ & $2.55 \pm 0.10$ \\
\hline & \multicolumn{5}{|c|}{ Mineral+Organic fertilization system } \\
\hline Winter wheat & $182 \pm 18$ & $0.76 \pm 0.08$ & $0.43 \pm 0.13$ & $2.4 \pm 0.80$ & $2.40 \pm 0.04$ \\
\hline Sugar beet & $197 \pm 8$ & $0.75 \pm 0.03$ & $0.25 \pm 0.02$ & $1.3 \pm 0.13$ & $2.63 \pm 0.02$ \\
\hline Corn for grain & $220 \pm 10$ & $0.84 \pm 0.05$ & $0.52 \pm 0.13$ & $2.4 \pm 0.69$ & $2.60 \pm 0.04$ \\
\hline Spring barley & $254 \pm 5$ & $0.99 \pm 0.02$ & $0.48 \pm 0.11$ & $1.9 \pm 0.46$ & $2.57 \pm 0.03$ \\
\hline Sunflower & $257 \pm 14$ & $0.99 \pm 0.06$ & $0.68 \pm 0.05$ & $2.6 \pm 0.26$ & $2.60 \pm 0.03$ \\
\hline Vetch+oats & $242 \pm 34$ & $0.96 \pm 0.13$ & $0.69 \pm 0.11$ & $2.9 \pm 0.48$ & $2.53 \pm 0.03$ \\
\hline
\end{tabular}

a Mean \pm S.D. (standard deviation, $\sigma), n=4$;

Table 2

Summarized results of two-way ANOVAs for soil general biochemical parameters

\begin{tabular}{llccc}
\hline Dependent variables & Independent variables ${ }^{\mathbf{a}}$ & $\mathbf{d . f .}^{\mathbf{b}}$ & $\mathbf{F}^{\mathbf{c}}$ & P-value $^{\mathbf{d}}$ \\
\hline Microbial biomass carbon $\left(C_{\text {mic }}\right)$ & Fertilization system & 1 & 6.24 & $0.017^{*}$ \\
& Crop types & 5 & 20.79 & $<0.001^{* * *}$ \\
& Interaction & 5 & 0.32 & 0.89 \\
\hline Microbial quotient $\left(C_{\text {mic }}: C_{\text {org }}\right)$ & Fertilization system & 1 & 0.90 & 0.35 \\
& Crop types & 5 & 20.21 & $<0.001^{* * *}$ \\
& Interaction & 5 & 0.66 & 0.66 \\
\hline Basal soil respiration $\left(C-C \mathrm{O}_{2}\right.$ rate $)$ & Fertilization system & 1 & 0.88 & 0.35 \\
& Crop types & 5 & 4.61 & $0.002^{* *}$ \\
& Interaction & 5 & 2.98 & $0.023^{*}$ \\
\hline Metabolic quotient & Fertilization system & 1 & 0.88 & 0.35 \\
$\left(q C O 2=C-C O_{2}: C_{m i c}\right)$ & Crop types & 5 & 4.61 & $0.002^{* *}$ \\
& Interaction & 5 & 2.98 & $0.024^{*}$ \\
\hline Total organic carbon $\left(C_{\text {org }}\right)$ & Fertilization system & 1 & 15.91 & $<0.001^{* * *}$ \\
$(0-20 \mathrm{~cm})$ & Crop types & 5 & 7.95 & $<0.001^{* * *}$
\end{tabular}

a Fertilization system (Min+Org vs Org) and crop types (six cereal and row crops in 6-years crop rotation) were the independent variables.

${ }^{\mathbf{b}}$ degree of freedom - the number of given elements (e.g. two fertilization systems or six crops) inside of independent variables minus 1;

' F-test or Fisher's criteria;

${ }^{\mathrm{d}}$ confidence level. P values: $* * *=\mathrm{P}<0.001 ; * *=0.001<\mathrm{P}<0.01 ; *=0.01<\mathrm{P}<0.05$

Basal soil respiration $\left(\mathrm{C}-\mathrm{CO}_{2}\right.$ rate) serves as the indicator of metabolic activity of soil microorganisms or the content of organic carbon potentially mineralizable up to $\mathrm{CO}_{2}$. The $\mathrm{CO}_{2}$ emission from the soil to the atmosphere is the main cause of soil $\mathrm{C}$ loss [26] and it provides an early indication of soil $\mathrm{C}$ level when changes in organic $\mathrm{C}$ 
due to management practices are not detectable over a short period [27-28]. According to two-way ANOVAs analysis data (table 2) the fertilization systems revealed no significant influence upon $\mathrm{C}-\mathrm{CO}_{2}$ rate. But differences between means within a crop types identified using paired t-tests were significant for microbial communities from soils under winter wheat, sugar beet, corn for grain, and spring barley. The most evident differences were observed for microbial communities from soils of Org plots cultivated with corn for grain and followed spring barley, respectively, with the most enhanced and the most reduced levels of $\mathrm{CO}_{2}$ elimination. At mixed Min+Org amendment the soil cropped with sugar beet characterized by the least quantity of $\mathrm{CO}_{2}$ elimination, but the soil under sunflower and followed vetch + oats - by the biggest intensity of respiration. Thus, the soil respiration was significantly higher in soil under crop chain the winter wheat - sugar beet - corn for grain at Org fertilizers amendment in comparison to Min+Org system. It was found, the nitrogen fertilization inhibits soil microbial respiration regardless of the form of nitrogen applied [29]. The possible explanation of enhanced $\mathrm{CO}_{2}$ evolution from soil, cropped with corn for grain, may be the existence of significant deficiency of mobile N. Conform to general N-regulation processes by the content of soil accessible N [30], the decomposition of soil organic carbon substances, containing simultaneously and organic $\mathrm{N}$, can be initiated and the elimination of $\mathrm{CO}_{2}$ is enhanced. It was hypothesized that organic cropping systems would reduce soil $\mathrm{CO}_{2}$ emission and increase $\mathrm{C}$ storage compared to conventional cropping systems [31]. Last cited researchers have found that the soil $\mathrm{CO}_{2}$ emission rate at peak times in the Org system was higher than the conventional (Conv) that is mineral fertilization system. However, even if the cropping systems had a temporary impact on the rate of soil $\mathrm{CO}_{2}$ emissions, the soil $\mathrm{C}$ output calculated as the average of cumulative $\mathrm{CO}_{2}$ emission over the 3-year period did not show significant differences between the Org and Conv systems. On the other hand, according to last researchers, the $\mathrm{C}$ input in the Org system was higher than in the Conv (9.46 $\mathrm{Mg} \mathrm{C}^{-1}$ vs. $5.57 \mathrm{Mg} \mathrm{C} \mathrm{ha}^{-1}$ ) as well as the $\mathrm{C}$ input/output ratio (1.10 vs. 0.72) [31]. The 3-year average of $\mathrm{C}_{\text {org }}$ content and $\mathrm{C}$ stock was higher in the Org than in the Conv system. Still, are needed to verify if $\mathrm{C}$ limitation for soil microbial growth and nitrogen limitation for crop growth in the organic system could hinder soil C accumulation over a longer period.

Metabolic quotient $\left(q \mathrm{CO}_{2}\right)$ was offered for the quantification of environmental effects on the microbial communities in soils [9]. The parameter $\mathrm{qCO}_{2}$ indicates the efficiency by which soil microorganisms use C-resources in the soil, and it is expected that stressed soils will provide higher $\mathrm{qCO}_{2}$ values than less-stressed soils [32]. The same, it reflects the microbial requirements of maintenance energy [20]. The results of our research show two certain crop chains (table 1). First one: spring barley-sunflower-vetch+oats were not affected by fertilizers, second - winter wheat-sugar beet-corn for grain had lower $\mathrm{qCO}_{2}$ values at Min+Org than at Org fertilization. It could be explained by better supply of microorganisms and crops with mobile $\mathrm{N}$ at Min $+\mathrm{Org}$, while at Org farming it may be as was noticed by Mancinelli et al [31] the temporary impact on the rate of soil $\mathrm{CO}_{2}$ emissions due to use of organic substances which simultaneously contain $\mathrm{C}$ and $\mathrm{N}$ elements. In general, the metabolic quotient was not influenced significantly by fertilization system ( $\mathrm{P}$ $>0.05$ ) (table 2). The $\mathrm{qCO}_{2}$ values of typical chernozem (soil pH 6.6-7.1) under 6 crops (Northern Moldova) ranged between 1.5-3.6 $\mathrm{mg} \mathrm{CO}_{2}-\mathrm{C} \mathrm{g}^{-1} \mathrm{C}_{\text {mic }} \mathrm{h}^{-1}$ (mean=2.8) and 1.7-2.9 $\mathrm{mg} \mathrm{CO}_{2}-\mathrm{C} \mathrm{g}^{-1} \mathrm{C}_{\text {mic }} \mathrm{h}^{-1}$ (mean=2.3), respectively, at Org and Min+Org fertilization, and were lower in comparison to the mean values 3.5 and $3.6 \mathrm{mg} \mathrm{CO}_{2}-\mathrm{C} \mathrm{g} \mathrm{g}^{-1} \mathrm{C}_{\text {mic }} \mathrm{h}^{-1}$, published by Trasar-Cepeda et al [33] for 40 climax soils and 45 cropped soils (respectively, soil $\mathrm{pH} 4.29$ and 5.83) in Galicia (NW Spain). It is known under acidic conditions the $\mathrm{qCO}_{2}$ is elevated since maintenance energy requirements of microbes are higher [20].

In summary, having in mind the interlinkage between the soil biotic component and biogeochemical cycling this research has followed the approach proposed by T.-H Anderson $[5,20]$ to use the eco-physiological indicators to estimate that one of soil management practices would be more or less detrimental than another, that is, Min+Org fertilization system versus Org one, only. It was published [20], that the $\mathrm{C}_{\text {mic }}: \mathrm{C}_{\text {org }}$ ratio of agricultural and forest soils at neutral $\mathrm{pH}$ is very similar and in the range between 2.0 and $4.4 \% \mathrm{C}_{\text {mic }}$ of total $\mathrm{C}_{\text {org }}$, depending on nutrient status and soil management. The metabolic quotient $\mathrm{qCO}_{2}$ ranged between 0.5 and $2.0 \mathrm{mg} \mathrm{C}^{-\mathrm{CO}_{2}} \mathrm{~g}^{-1} \mathrm{C}_{\text {mic }} \mathrm{h}^{-1}$ in neutral soils. Values below 2.0 for the $\mathrm{C}_{\text {mic }}$ : $\mathrm{C}_{\text {org }}$ ratio or above 2.0 for the $\mathrm{qCO}_{2}$ could be considered as critical for soils with a neutral soil $\mathrm{pH}$. The evaluation of our results on typical chernozem soil from North Moldova steppe under long-term agricultural use with the most protective fertilization systems (Org and Min+Org) and crop rotation has shown the $\mathrm{C}_{\text {mic }}$ : $\mathrm{C}_{\text {org }}$ ratio twice and more below 2.0 and the mean $\mathrm{qCO}_{2}$ values above 2.0. It means that Org fertilization system still doesn't make it possible to avoid the loss of organic $\mathrm{C}$ in arable typical chernozem. These data coincide with another published results, that soil $\mathrm{C}_{\text {org }}$ accumulation declines in long-term experiments ( $\left.>50 \mathrm{yr}\right)$ with farm manure applications as a new equilibrium is approached [34]. The both Org and Min+Org fertilization systems equally provides the soil carbon available for growth according to $\mathrm{C}_{\text {mic }}: \mathrm{C}_{\text {org }}$ ratio, but last one revealed lower level of $\mathrm{qCO}_{2}$ values. It could mean the mitigation of the negative consequences of long-term mineral fertilization by organic fertilizers.

\section{Conclusion}

The crop types had a more considerable impact on the soil microbial biomass and community biochemical activity compared to long-term Organic or mixed Mineral+Organic fertilizers amendments. The chain of crops: winter wheat - sugar beet - corn for grain revealed a strong influence on soil microbial communities resulted in higher metabolic 
quotient $\left(\mathrm{qCO}_{2}\right)$ at Org system of fertilization. It could demonstrate a less efficiency of soil organic carbon use may be because of a more acute need for accessible N. Next chain of three crops: spring barley - sunflower - vetch + oats revealed higher microbial quotient $\left(\mathrm{C}_{\text {mic }}: \mathrm{C}_{\text {org }}\right.$ ratio) and least $\mathrm{qCO}_{2}$ values. The organic fertilizer is able to mitigate the negative consequences of long-term mineral fertilization.

\section{Acknowledgements}

The author thanks Prof. B. Boincean and Dr. L. Nica for the given possibility of soil sampling from long-term field experiment (Balti, ICCC Selectia), the same, researchers O. Daraban and Ia. Druta for experimental assistance.

\section{References}

[1]. Tilman, D. Proceedings of the National Academy of Sciences, 1999, 96, 5995-6000.

[2]. Galloway, J. N.; Dentener, F. J.; Capone, D. G.; Boyer, E. W.; et al. Biogeochemistry, 2004, 70, $153-226$.

[3]. Smith, P. Eur. J. Agronomy, 2004, 20, 229-236.

[4]. Van Groenigen K.-J.; Bloem, J.; Baath, E.; Boeckx, P.; Rousk, J.; Bode, S.; Forristal, D.; Jones, M. B. Soil Biol. Biochem., 2010, 42, 48-55.

[5]. Anderson, T.-H.; Domsh, K. H.; 2010. Soil Biol. Biochem., 2010, 42, 2039-2043.

[6]. Kemmitt, S. J.; Lanyon, C. V.; Waite, I. S.; Wen, Q.; Addiscott, T. M.; Bird, N. R. A.; O’Donnell, A. G.; Brookes, P. C. Soil Biol. Biochem., 2008, 40, 61-73.

[7]. Ekschmitt, K.; Liu, M.; Vetter, S.; Fox, O.; Wolters, V. Geoderma, 2005, 128, 167-176.

[8]. Fontaine, S.; Barot, S. Ecol. Lett., 2005, 8, 1075-1087.

[9]. Marschner, B.; Kabitz, K. Geoderma, 2003, 113, 211-235.

[10]. Kaschuk, G.; Alberton, O.; Hungria, M. Soil Biol. Biochem., 2010, 42, 1-13.

[11]. Corcimaru, S.; Mereniuc, Gh.; Boincean, B.; Bugaciuc, M. Bul. ASM. St. vietii. 2011, 2(314), 166-170.

[12]. Nannipieri, P.; Landi, L.; Badalucco, L. Agronomia, 29, 312-316.

[13]. Boincean, B. In: Technical crops for modern agriculture. Presa univ. balteana: Balti, 2008. pp. 115-119.

[14]. Nica, L. In: Technical crops for modern agriculture. Balti, 2008., pp. 167-169.

[15]. Stadnic, S. Agricultura Moldovei, 2006, 4, 16-18.

[16]. Blagodatskii, S. A.; Blagodatskaia, E. V.; Gorbenko, A. Ju.; Panikov N. S. Pedology. 1987, 4, 64-71.

[17]. Isermeyer H. In: Alef, K., Nannipieri, P. (Eds.), Methods in Applied Soil Microiology and Biochemisty. Academy: London, 1995. pp. 214-216.

[18]. Wardle, D. A.; Ghani, A. Soil Biol. Biochem. 1995, 27, 1601-1610.

[19]. Arinushkina, E.V. Agrochemical methods of soil analysis; Nauka: Moscow, 1980. 150pp.

[20]. Anderson, T.-H. Agr., Ecosyst. Environ., 2003, 98, 285-293.

[21]. Ladygina, N.; Hedlund, K. Soil Biol. Biochem. 2010, 42, 162-168.

[22]. Groffman, P. M.; Eagan, P.; Sullivan,W. M.; Lemunyon, J. L. Plant and Soil, 1996,183, 61-67.

[23]. Bezemer, M. T.; Lawsons, C. S.; Hedlund, K.; Edwards, A. R.; Brook, A. J.; Igual, J. M.; Mortimer, S. R.; Van der Putten, W. J. Ecol., 2006, 94, 893-904.

[24]. Patra, A. K.; Le Roux, X.; Grayston, S. J.; Loiseau, P.; Louault, F. Bioresource Technol., 2008, 99, $3545-3551$.

[25]. Insam, H.; Domsch, K.H. Microbial Ecol., 1988, 15, 177-188.

[26]. Parkin, T. B.; Kaspar, T. C. Soil Sci. Soc. Am. J., 2003, 67, 1763-1772.

[27]. Fortin, M. C.; Rochette, P.; Pattey, E. Soil Sci. Soc. Am. J., 1996, 60, 1541-1547.

[28]. Grant, R. F. Soil Sci. Soc. Am. J., 1997, 61, 1159-1175.

[29]. Ramirez, K.S., Craine, J.M., Fierer, N., Soil Biol. Biochem., 2010, 42, 2336-2338.

[30]. Geisseler, D.; Horwath, W. R.; Joergensen, R. G.; Ludwig B. Soil Biol. Biochem., 2010, 42, 2058-2067.

[31]. Mancinelli, R.; Campiglia, E.; Di Tizio, A.; Marinari, S. Appl. Soil Ecol., 2010, 46, 134-142.

[32]. Insam, H., Haselwandtner, K. Oecologia, 1989,79, 174-178.

[33]. Trasar-Cepeda, C.; Leirós, M. C.; Seoane, S.; Gil-Sotres F. Appl. Soil Ecol., 2008, 39, 133-143.

[34]. Powlson, D. S.; Bhogal, A.; Chambers, B. J.; Coleman, K.; Macdonald, A. J.; Goulding, K. W. T.; Whitmore, A.P. Agr., Ecosyst. Environ., 2012, 146, 23-33. 